\title{
EVALUATION OF THE INNOVATION CULTURE IN AN INDUSTRIAL MAINTENANCE COMPANY
}

\author{
Délio Paes Oliveiraa, Camila de Sousa Pereira-Guizzo ${ }^{a}$ Alex Alisson Bandeira \\ Santos $^{a}$, Marcelo Vieira Figueiredo ${ }^{a}$ \\ a Graduate Program in Management and Industrial Technology, SENAI CIMATEC \\ University Center, Brazil
}

\begin{abstract}
The industrial maintenance area needs to guarantee control and avoid uncertainties and risks, aspects that can constitute barriers to innovation. Considering the importance of this productive sector focusing on competitiveness, this study aims to analyze the culture of innovation in an industrial maintenance company, located in Bahia, Brazil. The sample consisted of 100 employees. Participants answered the Innovation Culture Evaluation instrument. The answers were analyzed quantitatively using descriptive statistics. The main results demonstrated that the employees recognize the existence of a culture of innovation, but also emphasized the need of reinforcing communication and relationship with the organization's external context.
\end{abstract}

Keywords: culture of innovation; industrial maintenance; organizational culture.

\section{AVALIAÇÃO DA CULTURA DE INOVAÇÃO EM UMA EMPRESA DE MANUTENÇÃO INDUSTRIAL}

Resumo: A área de manutenção industrial precisa garantir controle e evitar incertezas e riscos, aspectos que podem se constituir em barreiras à inovação. Considerando a importância desse setor produtivo atentar-se para a competitividade, este estudo tem como objetivo analisar a cultura de inovação em uma empresa de manutenção industrial, localizada no estado da Bahia. A amostra foi composta por 100 colaboradores. Os participantes responderam ao instrumento Avaliação de Cultura de Inovação. As respostas foram analisadas quantitativamente por meio de estatística descritiva. Os principais resultados mostraram a percepção compartilhada pelos colaboradores de uma cultura de inovação, chamando a atenção a necessidade de fortalecer a comunicação e o relacionamento com o contexto externo à organização.

Palavras-chave: cultura de inovação; manutenção industrial; cultura organizacional.

\section{INTRODUCTION}

Organizational culture is a social interaction phenomenon where learning occurs through shared events and results [1]. This learning comes from the experience of solving problems of internal or external adaptation to the organization, in which the 
results were perceived as satisfactory and, therefore, considered able of being taught to new members [2].

The culture of innovation is a type of organizational culture with specific characteristics and factors that enable innovation [3]. An organization has a culture of innovation when it supports people who believe they can create something new and allows new daring things to happen with some regularity [4]. The culture of innovation consists on the shared innovation values and beliefs, combined with the organization's search for competitiveness [5].

The culture of innovation is a complex system composed of often paradoxical practices, which lead organizations to apparently inconsistent directions and require a delicate balance between different values [6]. Innovation cannot occur without ambiguity, and organizations that are not able to tolerate it in their work place environment tend to reproduce only routine actions [7]. The strategy should emphasize how the company intends to use innovation to create and capture value and define priorities among different opportunities [8]. The vision and mission must reflect intentionality through direct, quantitative and time-related objectives for creative products and services [9].

Organizational structures best suited to the development of innovative products must allow technological change to occur through integration between functions [10]. More organic and less mechanistic structures, in general, reinforce innovation, as they offer greater freedom in rules, are participatory and informal, consider different views, communication is face to face, have little bureaucracy, use interdisciplinary teams to break barriers and emphasize creative interaction [7].

Support mechanisms comprise a comprehensive system of rewards and incentives, autonomy in tasks, provision of qualification and professional training and general and immediate feedback [11]. It is important to recognize the protagonists of innovation, those who generated original ideas and those who acted in public development and implementation [12]. Providing access to knowledge and skills and granting power to make decisions that affect work have a reducing effect on barriers to innovation [13].

Leadership behaviors, such as showing respect for employees, considering their opinions in decisions that affect them and showing appreciation, recognizing their contribution to organizational goals, are crucial to encourage innovative behaviors [14]. Standards for dealing with failures are critical in a culture that fosters innovation. A failure describes a situation in which the best possible decision was taken based on the best information available and its results should enable learning. A culture of innovation seeks to experiment and learn from failures as quickly as possible [15].

Open and transparent communication, based on trust, contributes to innovation [16]. A trustful relationship in an organization is empowered when management and employees deal openly with each other [9]. Transparent conversations between senior management and subordinates are not easy to promote considering the general resistance of people or the need to filter information [17]. However, communication, as a promoter of the culture of innovation, must systematically include both the results obtained with innovation, as well as information about ideas rejected through feedback [12].

These organizational characteristics considered important for the culture of innovation can vary according to the productive sector, the size of the company, the service or product, among other aspects. The industrial maintenance sector is not always focused on innovation, given the accident risks. Maintenance itself needs to ensure control and avoid uncertainties and risks, aspects that can constitute barriers 
to innovation. However, it is a business sector as well as other ones that need to guarantee its competitive advantage and keep track of the trends of a tough market. Therefore, this study aims to analyze the culture of innovation in an industrial maintenance company, located in the state of Bahia.

\section{METHODOLOGY}

One hundred employees (out of one hundred forty five) of an industrial maintenance company, located in the state of Bahia, took part in this research. The company is an industrial maintenance world leader, which works with top-level safety practices, creates a maintenance culture, optimizes maintenance costs and improves plant performance. The participants in this study are between 23 and 62 years old (Average $=42.16$; $S D=9.1)$. Mostly that equals 96 people ( $96 \%$ of the sample) are male and only 4 participants are female. Regarding education, 77 participants have completed high school degree, 15 have incomplete higher education degree, 7 have completed higher education degree and only 1 has incomplete high school degree.

\subsection{Measuring Instrument}

Innovation Culture Evaluation - ICE. Instrument validated in Brazilian context by [5], with satisfactory psychometric qualities, whose objective is to analyze the culture of innovation in organizations. ICE has 85 items, which evaluates 15 factors: Culture Content; Interpersonal Communication; Institutional Communication; Leadership Characteristics and Actions; Diversity and Conflicts Resolution; Interest and Involvement of Individuals with Innovation Activities; Infrastructure for Innovation; Flexible Rules; Relationship with other organizations; Relationship with the Competitive Market; Legal Incentives; Relationship with customers; Demographic Environment; Perception of Innovation Results by Society; and Perception of the Innovation Results by the Organization. Items must be answered on a five-point Likert scale, which ranges from 1 (strongly disagree) to 5 (strongly agree).

\subsection{Data Collection Procedure and Data Analysis}

After the company's authorization and the approval of CIMATEC Research Ethics Committee, the potential participants were contacted. First, the Free and Informed Consent Term was explained to those interested in collaborating with the research. Those who expressed interest in collaborating signed the Term. Then, the Innovation Culture Assessment instrument was applied individually. Responses were analyzed quantitatively using descriptive statistics.

\section{RESULTS AND DISCUSSION}

Table 1 presents the results of the evaluation of the culture of innovation in the industrial maintenance company, according to the sample of employees. The results in Table 1 show that the employees tend to recognize the presence of the dimensions in the maintenance company studied. This result is positive, because it shows the 
perception shared by employees of a company that has a culture focused on innovation, an important characteristic for competitiveness.

Table 1. Evaluation of factors of the culture of innovation in an industrial maintenance company $(\mathrm{N}=100)$.

\begin{tabular}{|c|c|c|c|}
\hline Factor & Median & $\begin{array}{l}\text { Minimum } \\
\text { value }\end{array}$ & $\begin{array}{c}\text { Max } \\
\text { value }\end{array}$ \\
\hline \multirow{4}{*}{$\begin{array}{l}\text { Culture Content } \\
\text { Interpersonal comunication } \\
\text { Institutional Communication } \\
\text { Leadership Characteristics and Actions }\end{array}$} & 4,00 & 3 & 5 \\
\hline & 4,00 & 2 & 5 \\
\hline & 4,00 & 2 & 5 \\
\hline & 4,00 & 3 & 5 \\
\hline \multirow{3}{*}{$\begin{array}{l}\text { Diversity and Conflict Resolution } \\
\text { Interest and Involvement of Individuals } \\
\text { with Innovation Activities } \\
\text { Infrastructure for Innovation }\end{array}$} & 4,00 & 1 & 5 \\
\hline & 4,00 & 3 & 5 \\
\hline & 4,00 & 1 & 5 \\
\hline \multirow{8}{*}{$\begin{array}{l}\text { Flexible Rules } \\
\text { Relationship with other organizations } \\
\text { Relationship with the Competitive } \\
\text { Market } \\
\text { Legal Incentives } \\
\text { Customer Relationship } \\
\text { Demographic Environment } \\
\text { Perception of Innovation Results by } \\
\text { Society } \\
\text { Perception of Innovation Results by the } \\
\text { Organization }\end{array}$} & 4,00 & 2 & 5 \\
\hline & 4,00 & 2 & 5 \\
\hline & 4,00 & 2 & 5 \\
\hline & 3,75 & 1 & 5 \\
\hline & 4,00 & 1 & 5 \\
\hline & 4,00 & 1 & 5 \\
\hline & 4,00 & 2 & 5 \\
\hline & 4,00 & 2 & 5 \\
\hline
\end{tabular}

The difference between the minimum and maximum values allows us to analyze five factors that obtained the most discrepancy in responses such as Diversity and Conflict Resolution, Legal Incentives, Relationship with Customers and Demographic Environment. Except for Diversity and Conflict Resolution, which is related to the internal context of the organization, the other factors are part of the dimension associated with the relationship with the external context of the organization, with the attention of the investigated maintenance company in order to promote better conditions for reinforcing the culture of innovation. The communication of the results obtained with innovation must be strengthened not only among employees, but also with external customers and the region [12]. The recognition of the external environment can strengthen business and organizational performance, ensuring competitiveness.

As for the factors with less discrepancy, which suggest a more homogeneous evaluation by employees, only three were highlighted: Content of Culture, Characteristics and Actions of Leadership and Interest and Involvement of Individuals with Innovation Activities. These factors are part of the dimensions related to the strategies and conditions of the internal context for innovation, signaling important aspects of culture. As indicated by literature, communication and a trustful relationship between peers and between leaders and subordinates are important aspects in management and promote the culture of innovation [12, 16, 17]. Strategic planning, organizational structure, support mechanisms, leadership behavior and form of 
communication are important aspects of organizational culture, which directly influence the culture of innovation [16]. The sense of purpose clearly shared presents the desire to innovate and the commitment of top leadership, which impacts on culture [10], as can be seen in the results.

\section{CONCLUSION}

This study concluded that there is a perception shared by the collaborators of a culture of innovation in the industrial maintenance company investigated, showing that this productive sector can follow the market trends, without losing safety and reliability in its processes. The need to strengthen the relationship with the external context of the organization is due to the factors that obtained the most discrepancy between the minimum and maximum values of the response scale. Although government policies do not encourage the development of innovation in organizations, being aware of the different legal incentives and expanding business through new products and customers are important aspects of competitiveness.

This study was carried out in just one maintenance company. Although it was carried out with a representative sample, the results should not be generalized to other industrial maintenance companies. It is suggested that further studies are conducted in different organizations of this industrial sector.

\section{REFERENCES}

\section{${ }^{1}$ REVILLA, E. O dilema da criatividade. RAE-Revista de Administração de} Empresas, v. 59, n. 2, p. 149-153, 2019.

${ }^{2}$ SCHEIN, E. H. Organizational culture and leadership. John Wiley \& Sons, 2004.

${ }^{3}$ GODOY, R. S. P.; PEÇANHA, D. L. N. Cultura organizacional e processos de inovação: um estudo psicossociológico em empresa de base tecnológica. BoletimAcademia Paulista de Psicologia, v. 29, n. 1, p. 142-163, 2009.

${ }^{4}$ EUCHNER, J. Building a Culture of Innovation. Research Technology Management, v. 59, n. 6, p. 10-11, 2016.

${ }^{5}$ BRUNO-FARIA, M. F.; FONSECA, M. V. A. Medida da cultura de inovação: Uma abordagem sistêmica e estratégica com foco na efetividade da inovação. Revista de Administração e Inovação, v. 12, n. 3, p. 56-81, 2015.

${ }^{6}$ PISANO, G. P. Creative Construction: The DNA of Sustained Innovation. Public Affairs, 2019. 
${ }^{7}$ AHMED, P. K. Culture and climate for innovation. European journal of innovation management, v. 1, n. 1, p. 30-43, 1998.

8 PISANO, G. P. The hard truth about innovative cultures. Harvard Business Review, 2019. Disponível em: https://hbr.org/2019/01/the-hard-truth-aboutinnovative-cultures . Acessado em: 19/12/2019.

${ }^{9}$ MARTINS, E.; MARTINS, N. An organisational culture model to promote creativity and innovation. SA Journal of Industrial Psychology, v. 28, n. 4, p. 58-65, 2002.

10 TIDD, J.; BESSANT, J.; PAVITT, K. Gestão da inovação. 3ed. São Paulo: Artmed, 2008.

11 HARTMANN, A. The role of organizational culture in motivating innovative behaviour in construction firms. Construction innovation, v. 6, n. 3, p. 159-172, 2006.

12 TRÍAS DE BES, F.; KOTLER, Philip. A bíblia da inovação. São Paulo: Leya, 2011.

13 DEMIRCIOGLU, M. A. The effects of empowerment practices on perceived barriers to innovation: Evidence from public organizations. International Journal of Public Administration, v. 41, n. 15, p. 1302-1313, 2018.

${ }^{14}$ HOGAN, S. J.; COOTE, L. V. Organizational culture, innovation, and performance: A test of Schein's model. Journal of Business Research, v. 67, n. 8, p. 1609-1621, 2014

${ }^{15}$ BENNETT, N.; PARKS, J. M. Struggling to innovate? Examine your structure, systems, and culture. Business Horizons, v. 58, n. 5, p. 563-569, 2015.

${ }^{16}$ MARTINS, E. C.; TERBLANCHE, F. Building organisational culture that stimulates creativity and innovation. European journal of innovation management, v. $6, n$. 1 , p. 64-74, 2003.

${ }^{17}$ WLADAWSKY-BERGER, I. Honest Conversations - The Key to a Winning Transformational Strategy. Disponível em: https://blog.irvingwb.com/blog/2020/02/honest-conversations-the-key-to-a-winningstrategy.html . Acesso em: 04/04/2020. 